\title{
Reinterpreting the Relationship between the Caste System and Marxism
}

\author{
Yash Chauhan $^{1}$ \\ ${ }^{1}$ The International School of Bangalore (TISB), Bangalore, India \\ E-mail: yash.chauhan@,gmail.com
}

\begin{abstract}
In India, sixty years ago it was irrefutable that the structure of the caste system paralleled the Marxist view of class organization, in terms of the lower castes' lack of vertical mobility, dependence on hereditary division of labour, and deficiency of capital and land. In fact, since its emergence in 1964, the Communist Party of India (Marxist) (CPI(M)) has maintained that it would be in the best interest of lower caste individuals to support a Marxist agenda to launch nationwide class struggle to free themselves from the shackles of the caste system. It is also true that, in the 1970 s, $85 \%$ percent of lower caste individuals made up the bottom $35 \%$ of India's financial ladder, leading to the quotidian Marxian argument that the lower castes can be equated to the proletariat of Western Society. ${ }^{1}$ While these arguments might have some truth to them, this essay will explore why India, over the last sixty years, has endured too great of a reformation in terms of the caste system to simply be equated to the Marxist class organization. The disparity between the negativism of the $\mathrm{CPI}(\mathrm{M})$ and the current extent of oppression of the lower caste is shown, through the exploration of logical incorencies on the part of the CPI(M) and the lower caste perception of the policies directed at them by both left and right-wing political parties. Furthermore, it is established why the notion of an entire Marxist class revolution no longer has political appeal amongst the lower caste: the reservations and affirmative action on the part of the current administration. Yet it is still conceded that, although used in an orthogonally different manner, the Marxist framework can, to a certain extent, still be applied to current organization of the caste system in India.
\end{abstract}

Keywords: Marxism, Cultural Theory, Class, Oppression, Caste

\footnotetext{
1 Report of the Commissioner for Scheduled Castes and Scheduled Tribes, 1979-81 (Report 27), Government of India, 1983, p. 3.
} 


\section{Article}

This article, rather than looking to the Marxist framework to draw parallels from the bourgeois to the upper caste members of Indian society, will exclusively be focused on using the Marxist framework to draw parallels, if any, from the oppression faced by the proletariat to the oppression faced by local caste members in modern India. For this article, it must be noted that the lower caste will be considered as those part of Scheduled Castes (SC), Scheduled Tribes (ST), and Other Backward Castes (OBC) groups. Furthermore, for this article, oppression will be interpreted as marginalization of a particular group in terms of occupational and financial status, rather than considering it a product of individual prejudice and societal perception. And, lastly, this article refers to the proletariat as those part of the working-class who have no access to capital and are irretrievably bound by their current occupational position.

In India, according to the $\mathrm{CPI}(\mathrm{M})$, the caste system is all pervasive, seeping into the very fabric of Indian society not just on account of the systematic disadvantages lower caste face in terms of attaining financial freedom but also on account of the social stigmatization they face. Unlike the muslim minority in India, lower caste individuals have not even the slightest of upper-class origin and occupied no time in India with complete hegemony. This historical notion of inferiority is reinforced with their recurring poverty cycle, wherein their caste does not allow for them to build wealth and their lack of wealth provokes the association of poverty with their caste. Furthermore, it must also be argued that the caste system is so deeply rooted in this country that even farmers in the state of Maharashtra who have the same amount of land that produces the same amount - and type - of agricultural produce are disproportionately undervalued if they are from lower castes. As unfortunate as this is, it hints upon a greater the fiction of class that is predicated solely on occupational status in India, as, while these farmers could own the same land, one of them evidently is part of higher class on the basis of his caste. This might lead some to the conclusion that, no matter the financial equity that is created between castes, the reverberations of the caste system will never go away. In fact, it is even argued, by Marxist scholar Gail Omvedt, that the casteist system is the equivalent of an Indian feudalistic system, and "the struggle against the casteist system is the struggle against the underlying feudalistic order of this country." ${ }^{2}$ The effect of this comparison is implication of the notion that, as much as the deeply ingrained feudal system was a peril to a free democracy in the western world, the caste system is peril to a free democracy in India is suggested, as all men are not created in equal in feudalistic or casteist world. This, of course, acts only to strengthen 
the position held by the CPI(M), which is that the only way for complete emancipation from caste is if there was a combined effort - from all left-leaning political parties, and their constituents - to relaunch a unified class struggle aimed at revolutionizing not only the occupational structure but also the social structure of India. Yet in light of India's recent reformation into a quasi-capitalistic society and a technological powerhouse from an almost entirely agrarian economy, the conditions of oppression that impell the CPI(M) to adopt this perilous proposal must be challenged.

The greatest argument, fifty years ago, that hinted upon the oppression of lower caste members was the phenomenon of hereditarily divined occupational positions that disproportionately affected lower caste families with low-paying and arguably inhumane jobs. The facts that the parliamentary constitution of lower caste members was only a fraction of what the representation of lower castes were as a percentage of India, only 10 percent of lower caste students graduated from high-school, and only a minority of lower caste families lived above the argument, did nothing but aid the argument that caste restricted the possibility of upward movement in terms of social stratum. Yet, fast-forward to today most surprisingly, there have been great developments that utterly excoriate this notion of the impossibility of class movement and constant oppression. The first, and perhaps most surprising, of these developments is that recently there has been a great movement in India that involves upper caste families and individuals converting to the lower castes. One might initially see this movement of people as entirely ridiculous and unbelievably senseless, but this movement is not happening just for the sake of movement; rather, for the purpose of capitalizing on quantifiable benefits through a governmental policy that has changed the state of India irrevocably: the policy of reservations. In every regard, but particularly in the areas of education and public sector jobs, the current administration policy of reservation is bringing remarkable political support from lower caste individuals and great animosity from those castes to whom the burden of this policy will fall. ${ }^{3}$ The most consequential example of this policy would be the recent admission quotas of the Indian Institute of Technology (IIT), which are a group of universities generally considered among the most prestigious in India. In 2021, 49.5 percent of seats were reserved for those hailing from lower caste backgrounds, which means the entrance score requirements on the standardized exam (JEE) are significantly higher for those with upper caste origins; thus, impelling many to convert their caste for the purpose of increasing their acceptance rates. This policy of reservation is significant, in a Marxist sense, because it implies the increasing

${ }^{3}$ Subramanian, A. (2019). The Caste of Merit: Engineering Education in India. Cambridge, Massachusetts; London; England: Harvard University Press. 
possibility of emancipation from the ancient hereditarial occupational oppression and, to a certain extent, social emancipation, as, when more lower caste members get better educations, they will likely exceed the income of what was preordained for them; hence, reducing the severe income inequality in India and improving the societal perception of these lower castes. Therefore, if extrapolated, this argument would hint that, because of the recent and continuing changes in India, the societal oppression faced by the lower castes is becoming incomparable with that faced by the proletariat in 19th century Europe, especially in terms of educational and job opportunities.

The second of these developments is a more nuanced interpretation of a point briefly mentioned in the preceding paragraph: the fact that the lower caste political support for the CPI (M) is waning and the lower caste support of right-wing political parties is increasing in India. It might seem surprising that the support for the current administration (BJP) is increasing in spite of the BJP's affirmation of Hindutva ${ }^{4}$, a right-wing ideology that aims to reinvigorate the hindu spirit in India, as the conception of the caste system is so heavily intertwined with Hinduism. Yet, the BJP's political strategy of increasing reservations, not isolating those from lower castes from the core constituency, and creating animosity between Hindu and Muslism groups - rather than internal division, has enabled them to recapture political support from critical lower caste groups. The CPI (M), on the other hand, has had a rather equivocal political strategy, as there appears to be a great disparity between their idealism of what the caste system should look like today and the policies they support on this issue. The CPI(M)'s position on the caste system is surprisingly similar to the views held by the Republican party on the issue of race in the United States: for racism not to exist, there must no longer be the characterization and label of race and, therefore, affirmative action. By the same token, $\mathrm{CPI}(\mathrm{M})$ holds that the characterization and segregation of caste as immoral and that the idealism of today's India should be that caste is no longer a factor in the allocation of jobs and university placements. This is no doubt a politically unpopular position, even among lower castes as it would strip them all of all affirmative action programs, so, instead of having a policy in-line with their idealism, the CPI(M) reservedly supports reservations for political benefit. This equivocation on the part of CPI(M), rather than gaining them votes, has caused many of lower caste members to shift their political preference to the BJP, who, although have not advocated for the removal of casteism completely, have been consistent on their policies. ${ }^{5}$ While this information does not provide great insight into how the Marxist framework can be used to represent the casteist system, it does provide invaluable insight into whether the

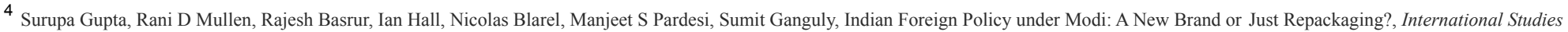
Perspectives, Volume 20, Issue 1, February 2019, Pages 1-45, https://doi.org/10.1093/isp/eky008

${ }^{5}$ Bandyopadhyaya (2002), Class Struggle and Caste Oppression: Integral Strategy of the Left, The Marxist Volume: 18
} 
current state of the casteist system will impell a collective class revolution against the ruling class. The truth is, of course, that the factors now could not be more oppositional to the necessary factors for there to be national class struggle on the part of lower castes to replace the BJP with a Marxist party like CPI (M). This must be qualified, rather antithetically, by the statement that India, perhaps 60 years ago, under a Congress administration, would be far more hospitable to a Marxist revolution than how inhospitable it would be today. In fact, one might go as far as to say that today it must be asked if it would be the upper caste members or lower caste members who more desire governmental reform of casteist policy.

The question at hand is not just whether similarities exist between the Marx's proletariat class and the lower castes in India because there certainly are - a lack of private ownership, primarily labourers; rather, the question is whether the relationship between the upper castes and lower castes in India mirrors the antagonistic relationship between the bourgeoisie and proletariat in industrial Europe. Furthermore, while the bourgeoisie and proletariat have to do with the process of production, the caste system has to do with the occupational roles individuals play in society. The answer, therefore, in short, is that these two relationships do not represent the same parallel, as the proletariat refers only to the group of people with relation to their role in production, so there are certainly both upper caste and lower caste proletarians. This is to say that, although there are disproportionately more lower caste individuals below the poverty line, it is not a universal phenomenon that the upper caste individuals will take the role of the bourgeoisie. Yet, there is one regard which undeniably, even today, shows the applicability of the Marxist framework to the casteist system: the issue of emancipation.

The concept of emancipation here refers not anymore to the lack of possibility for upward movability, as the increasing number of reservations is starting to ameliorate this problem, but rather to the fact that societally they are bound by the casteist system, in the sense that in the private sector they suffer from a lack of opportunity, a lack of support after being provided with a job or university place, and great vituperation and hostility if they show any intention of self-emancipation. Therefore, while the Marxist framework of inevitable emancipation is not manifested CPI(M)'s rather fantastical hope for entire class working-class emancipation from the oppressive capitalist society, it can perhaps be seen in the lower caste members' collective struggle for emancipation from the oppressive caste system they find themselves in. 


\section{Acknowledgements}

I would like to acknowledge and thank both Yale University and the Yale Marxism and Cultural Theory Working group for all their help and support over the last year. Let there be no doubt that this essay would not have been possible if I had not joined and been a part of the Yale M\&C group, as the knowledge gained through the discussions and readings was unquantifiably important to the construction of this manuscript.

\section{References}

[1] Government of India (1983), Report of the Commissioner for Scheduled Castes and Scheduled Tribes, 1979-81 ( Report 27)

[2] Omvedt, G. (1978). Towards a Marxist Analysis of Caste: A Response to B T Ranadive. Social Scientist, 6(11), 70-76. doi: $10.2307 / 3516612$

[3] Subramanian, A. (2019). The Caste of Merit: Engineering Education in India. Cambridge, Massachusetts; London; England: Harvard University Press, http://www.jstor.org/stable/j.ctvr33ddc

[4] Surupa Gupta, Rani D Mullen, Rajesh Basrur, Ian Hall, Nicolas Blarel, Manjeet S Pardesi, Sumit Ganguly (2019). Indian Foreign Policy under Modi: A New Brand or Just Repackaging?, International Studies Perspectives, Volume 20, Issue 1, https://doi.org/10.1093/isp/eky008

[5] Bandyopadhyaya (2002). Class Struggle and Caste Oppression: Integral Strategy of the Left, The Marxist Volume: 18, https://www.cpim.org/marxist/200203 marxist caste\&class_jbando.htm 